\title{
Cardiac surgery and hypertension: a dangerous association that must be well known
}

\author{
Cirurgia cardíaca e hipertensão: uma associação perigosa que deve ser bem conhecida
}

Shi-Min YUAN ${ }^{1}$, Hua JING²

RBCCV 44205-1277

\begin{abstract}
It is well-known that hypertension is a very common disease, and severe cerebrovascular accidents might occur if the blood pressure is not properly controlled. However, conditions associated with uncontrolled hypertension may be overlooked, and may become critical and eventually require a surgical intervention on an urgent basis. Coronary artery disease, acute aortic syndrome, congenital and valvular heart disease, and arrhythmias are under this topic of discussion. Of them, coronary artery disease including myocardial infarction and especially postinfarction myocardial rupture, and aortic dissection are major critical situations that physicians may encounter in clinical practice. The role that hypertension plays in these conditions can be complex, including hemodynamic, electrophysiological and biomolecular factors, where the latter may prevail in the current era. Coronary artery disease may be associated with a reduced nitric oxide synthesis. Transforming growth factor and matrix metalloproteinases have been observed in relation to aortic syndrome. Wnt, p38 and JNK signaling pathway may be involved in the development of ventricular hypertrophy responsible for cardiac arrythmias. Various gene phynotypes may present in different congenital heart defects. This article is to present these conditions, and to
\end{abstract}

further discuss the possible etiologies and the potential treatment strategies so as to highlight the relevance at a prognostic level.

Descriptors: Cardiac Surgical Procedures. Heart Diseases. Hypertension.

\section{Resumo}

É sabido que a hipertensão é uma doença muito comum, e que os acidentes cerebrovasculares graves podem ocorrer se a pressão sanguínea não for apropriadamente controlada. Contudo, as condições associadas à hipertensão não controlada podem ser negligenciadas, e tornarem-se críticas, necessitando, eventualmente, uma intervenção cirúrgica urgente. Doença coronariana, síndrome aórtica aguda, cardiopatias congênitas, valvopatias e arritmias são sob este tópico de discussão. Dentre eles, a doença corornariana, inclusive o infarto do miocárdio e especialmente a ruptura cardíaca pós-infarto e a dissecção aórtica, são as situações críticas principais que os médicos podem encontrar na prática clínica. $O$ papel que a hipertensão desempenha nessas condições pode ser complexo, incluindo fatores
1. MD, PhD; Postdoctoral Researcher, Department of Cardiothoracic Surgery, Jinling Hospital, School of Clinical Medicine, Nanjing University. Nanjing, China.

2. Professor and Head, Department of Cardiothoracic Surgery, Jinling Hospital, School of Clinical Medicine, Nanjing University. Nanjing, China.
Correspondence address:

Shi-Min Yuan

Department of Cardiothoracic Surgery, Jinling Hospital, School of Clinical Medicine, Nanjing University, Nanjing, China

E-mail: shi_min_yuan@yahoo.com 
hemodinâmicos, eletrofisiológicos e biomoleculares, nos quais o último pode prevalecer atualmente. A doença coronariana pode associar-se com uma redução na síntese de óxido nítrico. Fator de crescimento transformador e nas metaloproteinases da matriz têm sido observados em relação à síndrome aórtica. $\mathrm{O}$ Wnt, p38 e a via de sinalização JNK caminho podem estar implicado no desenvolvimento da hipertrofia ventricular responsável por arritmias cardíacas.

\section{INTRODUCTION}

Hypertension is a very common disease among general individuals. Uncontrolled hypertension is associated with potentially reversible structural and functional changes in the cerebral circulation [1], and at an increasing risk for cerebral, cardiac, and renal events [2]. However, this condition has not been a topic of much evaluation as to being defined within the field of cardiac surgery. It is particularly of great importance for cardiac surgeons and physicians from other specialties to be acknowledged of what and how cardiac surgical issues may develop associated with hypertension and may eventually warrant a surgical intervention. As a result, several conditions, such as coronary artery disease [3], acute aortic syndrome [4], congenital [5,6] and valvular heart disease [7], and arrhythmias [8] can be involved. The role that hypertension plays in these conditions can be complex, including hemodynamic, electrophysiological and biomolecular factors. In some occasions, there is a reciprocal causation between hypertension and the cardiovascular disorders, for instance, aortic syndrome [9], and coarctation of the aorta [10]. This article is to present these conditions, and further discuss the etiologies and the treatment strategies so as to highlight the relevance at a prognostic level.

\section{CARDIAC SURGICALCONSEQUENCES}

\section{Coronary artery disease}

Hypertension is associated with an increased risk of cardiovascular events. It has been regarded as one of the three classical risk factors for coronary artery disease besides hyperlipidemia and smoking. Epidemiological data have indicated a close link between hypertensive and coronary events. This concept has been established by many observational studies, showing a strong association between high blood pressure and the incidence of ischemic heart disease, stroke and peripheral vascular disease [11]. As a contributing factor to coronary artery disease, hypertension may impact by way of: 1) an intrinsic tendency to excessive proliferative and hypertrophic activity in
Vários fenótipos dos genes podem apresentar defeitos cardíacos congênitos diferentes. Este artigo apresenta essas condições, e discute, além disso, possíveis etiologias e as estratégias de tratamento potenciais bem destacar sua importância quanto a prognóstico.

Descritores: Procedimentos Cirúrgicos Cardíacos. Cardiopatias. Hipertensão. vascular tissue associated with increased endocrine and local paracrine effects; 2) the impact of the common risk factors, such as high blood pressure, that exaggerate and accelerate atherosclerotic process; and 3) hemodynamic factors, which may destabilize vascular lesions and precipitate acute events [3].

A modest short-term reduction in blood pressure confers a reduction in coronary artery disease events of about $16 \%$ [12]. Metaanalyses have shown that a reduction of $1 \mathrm{mmHg}$ in diastolic blood pressure produces a 2-3\% decline in risk of coronary heart disease [13]. For those 60 to 69 years of age, a $10 \mathrm{mmHg}$ lower systolic blood pressure is associated with about one-fifth lower risk of a coronary artery disease event [14].

The development of myocardial ischemia in patients with hypertension is multifactorial. Increased afterload induced by hypertension results in an increase in left ventricular wall tension and transmural pressure, compromising coronary blood flow during diastole. The myocardial microvascular changes under hypertension could not satisfy increased metabolic and oxygen demand. Shear stress is associated with hypertension, and endothelial dysfunction causes impairment in the synthesis and release of the potent vasodilator nitric oxide (NO). A decreased NO level promotes the development and acceleration of arteriosclerosis and plaque formation [15].

Hypertension is one of the most frequent risk factors for acute myocardial infarction. As a risk factor, hypertension was observed in 55\% female and $35 \%$ male patients with myocardial infarction. In $10 \%$ of female patients, hypertension was the only risk factor for myocardial infarction [16]. The mechanisms through which hypertension contributes to the occurrence of myocardial infarction lie in: 1) common risk factors for the two diseases, including genetic risk, insulin resistance, sympathetic hyperactivity, and vasoactive substances such as angiotensin II, and 2) atherosclerosis and left ventricular hypertrophy that are induced by hypertension and contribute to the development of atherosclerosis and myocardial infarction. Mechanical stress on blood vessels caused by high blood pressure is an important factor in 
endothelial dysfunction, atherosclerotic progression and plaque rupture [17].

Hypertension can also be an important risk factor leading to myocardial rupture. Clinical observations revealed that $0.3 \%$ of the men with a highest systolic pressure less than $150 \mathrm{mmHg}$ had a rupture, while $1.6 \%$ of those with pressures between 170-189 mmHg ruptured. Diastolic blood pressure, past history of hypertension, and sustained hypertension after infarction may not predict the occurrence of rupture. However, 18/53 (34.0\%) patients with rupture had systolic hypertension $\geq 150 \mathrm{mmHg}$ sometime during the 24 hours before rupture, and 14/53 (26.4\%) had diastolic hypertension $\geq 95 \mathrm{mmHg}$ [18].

Both clinical observations and experimental studies revealed a reduced coronary reserve and an increased coronary resistance in both hypertensive subjects and animals [19,20]. Although conflicting results in NO importance for the regulation of vessel tone, a reduced NO synthesis was still considered a potential cause for an increased vascular resistance in arterial hypertension [20]. Inhibition of the endothelial NO synthase (eNOS) resulted in greater constriction in the spontaneous hypertensive rats at moderate-to-high pressures [21], while inhibition of the cyclooxygenase (COX) pathway did not affect the myogenic response in either WistarKyoto rats or spontaneous hypertensive rats [22]. These studies suggested that NO may be an important mediator of basal tone, especially at higher pressures. Wnt signaling pathway can be reactivated in response to the pathological cardiac remodeling, vascular damage and myocardial infarction; while inhibition of Wnt signaling may reverse the pathological changes [23]. After myocardial infarction, components of the Wnt/frizzled pathway were upregulated [24]. These results indicated that Wnt signaling pathway may be involved in the development of cardiac hypertrophy and coronary artery disease. Moreover, patients with acute coronary syndrome had higher levels of Dickkopf Related Protein 1 (DKK1) than controls [25].

\section{Acute aortic syndrome}

Moderate to severe hypertension is a universal risk factor for the development of acute aortic syndrome [26]. Hypertensive emergency is often associated with aortic dissection and aneurysms [27]. In individuals younger than 40 years of age, young patients with sustained systemic hypertension are at increased risk for aortic dissection [28]. The increasing rate of systolic blood pressure was observed to have a close relation with the extent of aortic dissection even in the condition of normal blood pressure [29]. Types $\mathrm{A}$ and $\mathrm{B}$ aortic dissections produce an intimal tear at the areas with largest hydraulic stress: the right lateral wall of the ascending aorta or the descending aorta proximal to the ligamentum arteriosum. The increased longitudinal shear stress on the aortic wall is more likely to be resulted from hypertension, where the vasa vasorum may thus suffer from decrease blood supplies and further lead to the medial stiffness and media ischemia [30].

The first genes identified to cause type A dissections were fibrillin-1, and receptors I and II of transforming growth factor (TGF)- $\beta$. The identification and characterization of these genes suggested that increased TGF- $\beta$ signaling plays a role in the pathogenesis of the aortopathies. The recent discovery that mutations in the vascular smooth muscle cell-specific $\beta$-myosin (MYH11) and $\alpha$-actin (ACTA2) may also cause this disorder [31]. Western blotting analysis demonstrated that the expression of matrix metalloproteinases (MMPs)-2, $-3,-9$, and -12, as well as intercellular adhesion molecule, were increased in hypertensive abdominal aortic aneurysm rats, accompanied by upregulation of $\mathrm{NF}-\kappa \mathrm{B}$ and Ets, suggesting that hypertension accelerated the progression of experimental abdominal aortic aneurysm through upregulation of NF- $\kappa \mathrm{B}$ and Ets. Destruction of elastic fibers was also significantly inhibited by transfection of chimeric decoy oligodeoxynucleotide in both hypertensive and normotensive rats [32]. Sangiorgi et al. [33] also observed increased MMP-9 in patients with type A or B aortic dissection.

Wei et al. [34] demonstrated increased expressions of MMP-2 and tissue inhibitor of metalloproteinase-2 in the cytoplasm of the vascular smooth muscle cells on the basis of 35 patients with acute aortic dissection, where $80 \%$ of the patients were hypertensive. A study of the same institute by Yang et al. [35] showed aortic dissection and aortic aneurysm were characterized by degeneration of the media accompanied by elastic fiber disruption, with uneven expression of TGF- $\beta_{1}$ in the aorta, which was the highest in the media. They also observed that the value of TGF- $\beta_{1}$ was lower in the aortic dissection than in the aortic aneurysm patients. These results suggested an apparently inflammatory reaction in the aortic diseases, with a stronger inflammation in the aortic aneurysm than in the aortic dissection. But further studies are required to compare severities of the two aortic lesions.

\section{Congenital heart defects}

The mechanism of hypertension in coarctation of the aorta is not fully understood. Kuroczyñski et al. [10] observed 25 adults with coarctation of the aorta, and found that their mean blood pressure was 182/97 $\mathrm{mmHg}$. However, blood pressure turned to be normal immediately after surgery in most patients, it remained slightly elevated (systolic blood pressure between $140-160 \mathrm{mmHg}$ ) in seven patients, and prolonged elevation of arterial pressure was noted in only one patient. Adult patients had lowered mean postoperative 
systolic blood pressure and decreased requirement for antihypertensive medication in more than half $(58 \%)$ of the patients following surgical repair of coarctation of the aorta over a mean follow-up of 37 months [36].

A similar study by Bhat et al. [37] on 84 patients concluded identical implications. However, some patients developed hypertension late after successful surgical repair of aortic coarctation. Weber et al. [38] noted that $28 \%$ patients developed systolic hypertension 7.8 years after repair of coarctation. They deduced that hypertension and arch obstruction appeared relating to unparalleled growth of the transverse aortic arch proximal to the repair site. But the renal factor, i.e., aortic constriction below the coarctation triggering the release of vasopressin and involved by angiotensin II offered a more plausible explanation for hypertension resulting from acute aortic coarctation [39].

Hypertension was reported in $20 \%$ of adult with Turner's syndrome of the 45,X karyotype, and in $14 \%$ of those having the mosaic pattern [40]. The risk of hypertension was 3fold higher in women with Turner's syndrome than those without. In particular, diastolic other than systolic blood pressure in Turner's syndrome patients was significantly higher [41]. According to some suggestions, hypertension in Turner's syndrome seems to be essential by nature [42]. But studies demonstrated elevated plasma renin activity in girls and young women with Turner's syndrome and hence the etiology of hypertension was hypothesized to be a renovascular disease [41].

Hypertension was found in 23/42 (55\%) patients with Williams-Beuren syndrome older than 15 years old, where antihypertensive medications were warranted in 14/23 $(61 \%)$ of the patients, including $\beta$-blocker only, $\beta$-blocker and diuretics, calcium blocker, angiotensin-converting enzyme inhibitor (ACEI), and diuretics only [43]. Researchers believed that the presence or absence of the neutrophil cytosol factor 1 (NCF1) gene on chromosome 7 was related to the developing hypertension in Williams syndrome [44]. Systemic vascular alterations caused by deletion of the elastin gene may occur early in individuals with Williams syndrome, leading to the clinical manifestation of systemic arterial hypertension unresponsive to drug treatment [45].

The relation between hypertension and bicuspid aortic valve is not fully elucidated. Hypertension and bicuspid aortic valve are usually altogether associated with Turner's syndrome [46]. The etiology of hypertension in bicuspid aortic valve may at least be seen in the observations of eNOS expression. In patients with bicuspid aortic valves, eNOS expression was significantly lower in the individuals with arterial hypertension compared with the patients with normal blood pressure, but there was no correlation between blood pressure and eNOS expression [47].

\section{Valvular disease}

Hypertension is associated with development of aortic insufficiency and probably aortic stenosis as well. Hypertension can cause aortic root dilation, leading to significant aortic insufficiency. An acute rise in blood pressure may accentuate the degree of aortic insufficiency, and hypertension was also thought to accelerate the process of aortic sclerosis and cause mitral regurgitation. Experimental studies have shown that aortic insufficiency appeared with increase of mean pressure by as little as 20$50 \mathrm{mmHg}$; 6 of 9 animals showed aortic incompetence when mean aortic pressure was elevated $45-70 \mathrm{mmHg}$ [48]. Kim et al. [49] demonstrated no significant difference in the prevalence of aortic regurgitation between the normotensive and hypertensive subjects, perhaps because of their relatively young age, mild degree of hypertension, and otherwise healthy status.

Roman et al. [50] stated antecedent hypertension was strongly associated with the presence of idiopathic aortic root dilation as the cause of aortic regurgitation. Arterial hypertension and aortic stenosis are the two main pathological models of left ventricular systolic overload. Acute changes in blood pressure could significantly alter these indices as a consequence of concomitant changes in transvalvular flow. Hypertension can be present in $68 \%$ of patients with severe aortic stenosis [51]. In severe supravalvar aortic stenosis model, systemic arterial hypertension may result in significant impairement of the aortic compliance [52]. A study based on 3.39 million discharges in Ireland revealed that the prevalence of hypertension was $21.0 \%$ in the patients with aortic stenosis, and was $1.1 \%$ in those with aortic stenosis. Aortic stenosis and hypertension were significantly associated with an odds ratio of 4.0. In addition, the progression of stenosis might be prevented by blood pressure control [53].

Besides aortic valve disorder, mild-to-moderate mitral regurgitation was frequently detected on routine echocardiography in asymptomatic hypertensive patients [54]. Hypertension may impact on the transvalvular regurgitant blood flow by increasing systemic resistance. Mitral valve incompetence may vary as the pressure gradient through the mitral valve changes. The higher the systemic blood pressure and the poorer the left ventricular function, the more severe the mitral incompetence [55]. The coexistence of hypertension and valvular regurgitation may apparently lead to impaired left ventricular geometry and function. Patients with moderate valvular regurgitation had significantly higher circumferential end systolic wall stress and lower left ventricular contractility when compared to patients without valvular regurgitation [54].

\section{Cardiac arrhythmias}

Arrhythmias are common problems in hypertensive 
patients. Cardiac arrhythmias commonly observed in patients with hypertension include atrial fibrillation, premature ventricular contractions, and ventricular tachycardia. Various mechanisms playing a part in the pathogenesis of arrhythmias include altered cellular structure and metabolism, inhomogeneity of the myocardium, poor perfusion, myocardial fibrosis, and fluctuation in afterload. The increased afterload imposed on the left atrium secondary to increased blood pressure leads to impairment of the left atrium and left atrial appendage function plus increased left atrial size and thickness. In addition to these structural changes, these patients are predisposed to atrial fibrillation. With loss of atrial contribution in the presence of diastolic dysfunction, atrial fibrillation may precipitate overt heart failure [15].

Diastolic dysfunction of the left ventricle, left atrial size and function, and left ventricular hypertrophy were suggested as the underlying risk factors for supraventricular and ventricular arrhythmias in hypertensive individuals. Besides, there was an increased incidence of impairment of left ventricular diastolic filling and left atrial enlargement [8]. The development of left ventricular hypertrophy in hypertensive patients appears to be the main link between hypertension and ventricular arrhythmias, as patients with left ventricular hypertrophy are more likely to develop ventricular arrhythmias than the hypertensive population without [56-58]. A randomized study demonstrated a significant correlation between left ventricular hypertrophy and Lown grade of arrhythmia and late potentials, where the presence of late potentials was also found to correlate significantly with the grade of arrhythmia [59]. Currently, the implications of JNK and p38 signaling cascades in pro-hypertrophic regulatory role have been noted in the myocardium [60].

The hypertensive patients also had a higher prevalence of left bundle branch block and resting ST-T changes on the electrocardiogram [61]. Univariate analysis showed that systolic pressure, diastolic pressure, age, left ventricular posterior wall thickness, left ventricular mass index, and ischemic alterations on myocardial perfusion tests were significantly associated with complex arrhythmias, whereas systolic pressure and age were independently associated with complex arrhythmias as a result of multivariate regression analysis [62]. Observations of electrophysiological studies may interpret at least in part the development of arrhythmias in hypertensive patients. Signal averaged $\mathrm{P}$ wave may predict the prevalence of diastolic dysfunction in hypertensive patients. Moreover, P-wave dispersion was suggested as a novel predictor of atrial fibrillation [63]. QT interval variability in hypertensive patients with or without left ventricular hypertrophy may predispose the risk of ventricular arrhythmias [64]. Hypertensive patients have increased QTd values compared with controls, especially in the presence of left ventricular hypertrophy [49]. Short and long-term followup of antihypertensive medications by ACEIs or calcium antagonists may bring about a shortening QTd value [65].

\section{TREATMENT}

For initial antihypertensive therapy, a $\beta$-blocker may be preferable to a diuretic in the patients with angina. In the patients with diabetes or diabetic nephropathy, the therapy of choice is probably a diuretic plus an ACEI or possibly an angiotensin II receptor blocker. A long-acting dihydropyridine calcium channel blocker may be an alternative therapy in patients with isolated systolic hypertension who cannot take a diuretic or who responds poorly to diuretic therapy. Combinations of small doses of two drugs from different classes may also be effective in elderly patients. For example, a diuretic may be given with a $\beta$-blocker, an ACEI or an angiotensin II receptor blocker. In some patients, an ACEI and a calcium channel blocker may be given together [66]. Inhibition of NF- $\kappa \mathrm{B}$ and Ets could be a potential therapeutic strategy to treat abdominal aortic aneurysm in hypertensive patients [32]. Interventions on NO bioavailability may be very helpful in designing more effective prevention, diagnostic and therapeutic strategies to deal with coronary vascular dysfunction in hypertension and cardiovascular disease [67].

Thrombolytic therapy is the optimal choice for patients with acute myocardial infarction within 12 hours after the onset of the symptoms [68]. The principle of treatment choices for either percutenous transluminal coronary angioplasty or coronary artery bypass grafting will be guided by technical improvements in cardiology or surgery, local expertise, and patients preference. Percutenous coronary intervention is indicated for the diabetes patients with multivessel disease and in the patients with unprotected left main stenosis. The use of drug-eluting stents might change this situation $[69,70]$. For myocardial rupture, conservative treatment is not recommended as many patients develop congestive heart failure, cardiogenic shock, and death. Despite optimal treatment, mortality remains high and prognosis is dismal.

Resection of the descending thoracic aorta and replacement with a vascular prosthesis is associated with an increased risk of paraplegia, as opposed to endoluminal stenting. At present, endovascular repair and hybrid treatment with high technical success rates represent an attractive alternative for the treatment of aortic aneurysms due largely to its overwhelming advantages including less trauma, lower risk of surgical complications and morbidities and quicker recovery $[71,72]$.

Apart from antihypertension, patients with coarctation of the aorta and bicuspid aortic valve are commonly 
associated with Turners syndrome, leading to an increased risk to infective endocarditis. Therefore, prophylactic antibiotics are strongly recommended for the patients with Turner's syndrome with a susceptibility of bacteremia [73].

Percutaneous ablation has brought about some major complications including pulmonary vein stenosis, and thromboembolism, and atrioesophageal fistula [74]. In patients with lone atrial fibrillation resistant to medical therapies, off-pump video-assisted thoracoscopic epicardial pulmonary vein isolation offers an attractive alternative to on-pump Maze procedures in the surgical treatment of lone atrial fibrillation [75].

Valve surgery is recommended when patients become symptomatic in particular present with heart failure. Aortic valve replacement has been the standard surgical procedure for treatment of aortic valve regurgitation. The decision between a valve replacement and repair relies on the damage extent of the valve leaflets and the subvalvular apparatus. Aortic valve repair is most commonly performed in patients with aortic regurgitation caused by a dilated aortic annulus, conjoined cusp prolapse in bicuspid aortic valves, single cusp prolapse in tricuspid aortic valves, and aortic valve cusp perforation due to endocarditis [76]. Due to the longterm complications related to anticoagulation, thromboembolism, bleeding, and rapid prosthetic degeneration in the young population, the higher risk of endocarditis, and the poorer preservation of the ventricular function, mitral valve repair is superior to mitral valve replacement [77].

In summary, coronary artery disease, acute aortic syndrome, congenital and valvular heart diseases, and arrhythmias are conditions of cardiac surgery associated with hypertension. The underlying mechanisms responsible for the development of the cardiac events are still uncertain. Hemodynamic changes due to left ventricular hypertrophy were taken as major factors accounting for the development of coronary artery disease, acute aortic syndrome, valvular disorders and arrhythmias. Renal and genetic factors may explain the hypertension in some patients with congenital heart defects. Primary biochemical studies provided with alternative explanations for these hypertensive issues, such as NO, eNOS and TGF- $\beta_{1}$ activities. At any rate, importance should be always aware of for a prophylaxic purpose. Prompt diagnosis and treatment are helpful for the critically patients with a postinfarction myocardial rupture or aortic dissection.

\section{REFERENCES}

1. Lipsitz LA, Gagnon M, Vyas M, Iloputaife I, Kiely DK, Sorond F, et al. Antihypertensive therapy increases cerebral blood flow and carotid distensibility in hypertensive elderly subjects. Hypertension. 2005;45(2):216-21.
2. Messerli FH, Williams B, Ritz E. Essential hypertension. Lancet. 2007;370(9587):591-603.

3. Weber MA. Role of hypertension in coronary artery disease. Am J Nephrol. 1996;16(3):210-6.

4. Melo RO, Martin JF, Toledo JC, Braile DM. Acute aortic dissection associated with hypertensive emergency. Rev Bras Cir Cardiovasc. 2008;23(4):586-8.

5. Corso RB, Atik FA, Faber CN, Caneo LF. Involution of aneurysmal collateral arteries after correction of aortic coarctation. Rev Bras Cir Cardiovasc. 2008;23(4):572-4.

6. Silva VF, Real DS, Branco JN, Catani R, Kim HC, Buffolo E, et al. Bentall and De Bono surgery for correction of valve and ascending aortic disease: long-term results. Rev Bras Cir Cardiovasc. 2008;23(2):256-61.

7. Feguri GR, Macruz H, Bulhões D, Neves A, Castro RM, Fonseca L, et al. Aortic valve replacement with different types of prosthesis: are there differences in the outcomes during hospital phase? Rev Bras Cir Cardiovasc. 2008;23(4):534-41.

8. Yildirir A, Batur MK, Oto A. Hypertension and arrhythmia: blood pressure control and beyond. Europace. 2002;4(2):175-82.

9. Liu LYM, Tsai CT, Lan LWR, Hou CJY. Severe hypertension in a young adult resulting from middle aortic syndrome. Acta Cardiol Sin. 2008;24(1):43-6.

10. Kuroczyñski W, Hartert M, Pruefer D, Pitzer-Hartert K, Heinemann M, Vahl CF. Surgical treatment of aortic coarctation in adults: Beneficial effect on arterial hypertension. Cardiol J. 2008;15(6):537-42.

11. MacMahon S, Peto R, Cutler J, Collins R, Sorlie P, Neaton J, et al. Blood pressure, stroke, and coronary heart disease. Part 1, Prolonged differences in blood pressure: prospective observational studies corrected for the regression dilution bias. Lancet. 1990;335(8692):765-74.

12. McInnes GT. Hypertension and coronary artery disease: cause and effect. J Hypertens Suppl. 1995;13(2):S49-56.

13. Keil U. Coronary artery disease: the role of lipids, hypertension and smoking. Basic Res Cardiol. 2000;95(Suppl 1):I52-8.

14. Lawes CM, Bennett DA, Lewington S, Rodgers A. Blood pressure and coronary heart disease: a review of the evidence. Semin Vasc Med. 2002;2(4):355-68.

15. Riaz K, Forker AD, Ahmed A. Hypertensive heart disease. http://emedicine.medscape.com/article/162449-overview. Accessed on January 9, 2011.

16. Momcilov-Popin T, Stojsiæ D, Zeceviæ D, Vitiæ B, Stojsiæ A, Zeceviæ D. Hypertension as a risk factor in acute infarct in young people. Med Pregl. 1998;51(5-6):251-3. 
17. Rakugi H, Yu H, Kamitani A, Nakamura Y, Ohishi M, Kamide $\mathrm{K}$, et al. Links between hypertension and myocardial infarction. Am Heart J. 1996;132(1 Pt 2 Su):213-21.

18. Christensen DJ, Ford M, Reading J, Castle CH. Effect of hypertension on myocardial rupture after acute myocardial infarction. Chest. 1977;72(5):618-22.

19. Leschke M, Schoebel FC, Vogt M, Heintzen M, Kelm M, Motz W, et al. Reduced peripheral and coronary vasomotion in systemic hypertension. Eur Heart J. 1992;13(Suppl D):96-9.

20. Kelm M, Feelisch M, Krebber T, Deussen A, Motz W, Strauer $\mathrm{BE}$. Role of nitric oxide in the regulation of coronary vascular tone in hearts from hypertensive rats. Maintenance of nitric oxide-forming capacity and increased basal production of nitric oxide. Hypertension. 1995;25(2):186-93.

21. Garcia SR, Izzard AS, Heagerty AM, Bund SJ. Myogenic tone in coronary arteries from spontaneously hypertensive rats. $\mathrm{J}$ Vasc Res. 1997;34(2):109-16.

22. Garcia SR, Bund SJ. Nitric oxide modulation of coronary artery myogenic tone in spontaneously hypertensive and WistarKyoto rats. Clin Sci (Lond). 1998;94(3):225-9.

23. van de Schans VA, Smits JF, Blankesteijn WM. The Wnt/ frizzled pathway in cardiovascular development and disease: friend or foe? Eur J Pharmacol. 2008;585(2-3):338-45.

24. Blankesteijn WM, van de Schans VA, ter Horst P, Smits JF. The Wnt/frizzled/GSK-3 beta pathway: a novel therapeutic target for cardiac hypertrophy. Trends Pharmacol Sci. 2008;29(4):175-80.

25. Pérez Castrillón JL, San Miguel A, Vega G, Abad L, Andres Domingo M, Gonzalez Sagredo M, et al. Levels of DKK1 in patients with acute myocardial infarction and response to atorvastatin. Int J Cardiol. 2010;145(1):164-5.

26. de Monyé W, Murphy M, Hodgson R, Holemans J, Mcwilliams R. Acute aortic syndromes: pathology and imaging. Imaging. 2004;16(3):230-9.

27. Gupta PK, Gupta H, Khoynezhad A. Hypertensive emergency in aortic dissection and thoracic aortic aneurysm: a review of management. Pharmaceuticals. 2009;2(3):66-76.

28. Vogt BA, Birk PE, Panzarino V, Hite SH, Kashtan CE. Aortic dissection in young patients with chronic hypertension. Am J Kidney Dis. 1999;33(2):374-8.

29. White SR, Hall JB. Control of hypertension with nifedipine in the setting of aortic dissection. Chest. 1985;88(5):780-1.

30. Macura KJ, Corl FM, Fishman EK, Bluemke DA. Pathogenesis in acute aortic syndromes: aortic dissection, intramural hematoma, and penetrating atherosclerotic aortic ulcer. AJR Am J Roentgenol. 2003;181(2):309-16.
31. Milewicz DM, Guo DC, Tran-Fadulu V, Lafont AL, Papke $\mathrm{CL}$, Inamoto $\mathrm{S}$, et al. Genetic basis of thoracic aortic aneurysms and dissections: focus on smooth muscle cell contractile dysfunction. Annu Rev Genomics Hum Genet. 2008;9:283-302.

32. Shiraya S, Miwa K, Aoki M, Miyake T, Oishi M, Kataoka K, et al. Hypertension accelerated experimental abdominal aortic aneurysm through upregulation of nuclear factor $\mathrm{kB}$ and Ets. Hypertension. 2006;48(4):628-36.

33. Sangiorgi G, Trimarchi S, Mauriello A, Righini P, Bossone E, Suzuki T, et al. Plasma levels of metalloproteinases- 9 and -2 in the acute and subacute phases of type A and type B aortic dissection. J Cardiovasc Med (Hagerstown). 2006;7(5):307-15.

34. Wei T, Hong T, Xu DM, Song K Zheng JY, Yang SG, et al. The expression of matrix metalloproteinase-2 and tissue inhibitor of metalloproteinase-2 in the acute ascending aortic dissection. Chin J Clin Med. 2009;16(2):184-6.

35. Yang S-G, Wang C-S, Chen H, Hong T, Lai H, Zhu S-J. Comparison of TGF- $\beta 1$ distribution and expression in aortic wall of thoracic aortic dissection versus aneurysm. J Fudan Univ (Med Sci). 2008;35(5):681-6,691.

36. Hashemzadeh K, Hashemzadeh S, Kakaei F. Repair of aortic coarctation in adults: the fate of hypertension. Asian Cardiovasc Thorac Ann. 2008;16(1):11-5.

37. Bhat MA, Neelakandhan KS, Unnikrishnan M, Rathore RS, Mohan Singh MP, Lone GN. Fate of hypertension after repair of coarctation of the aorta in adults. Br J Surg. 2001;88(4):536-8.

38. Weber HS, Cyran SE, Grzeszczak M, Myers JL, Gleason MM, Baylen BG. Discrepancies in aortic growth explain aortic arch gradients during exercise. J Am Coll Cardiol. 1993;21(4):1002-7.

39. Salgado HC, Fazan Júnior R, Salgado MC. Vasopressor mechanisms in acute aortic coarctation hypertension. Braz $\mathrm{J}$ Med Biol Res. 1997;30(4):447-52.

40. Landin-Wilhelmsen K, Bryman I, Wilhelmsen L. Cardiac malformations and hypertension, but not metabolic risk factors, are common in Turner syndrome. J Clin Endocrinol Metab. 2001;86(9):4166-70.

41. Ho S-L, Gleeson HK, Smethurst L, Murray RD, Shalet SM. Hypertension and plasma renin activity in women with turner syndrome. Endocrine Abstracts. 2003;6:27. http:// www.endocrine-abstracts.org/ea/0006/ea0006p27.htm. Accessed on January 9, 2011.

42. Gravholt $\mathrm{CH}$, Hansen KW, Erlandsen M, Ebbehøj E, Christiansen JS. Nocturnal hypertension and impaired sympathovagal tone in Turner syndrome. J Hypertens. 2006;24(2):353-60. 
43. Eronen M, Peippo M, Hiippala A, Raatikka M, Arvio M, Johansson R, et al. Cardiovascular manifestations in 75 patients with Williams syndrome. J Med Genet. 2002;39(8):554-8.

44. No author listed. Williams syndrome. http://ghr.nlm.nih.gov/ condition=williamssyndrome. Accessed on January 9, 2011.

45. Sylos C, Pereira AC, Azeka E, Miura N, Mesquita SM, Ebaid M. Arterial hypertension in a child with Williams-Beuren syndrome (7q11.23 chromosomal deletion). Arq Bras Cardiol. 2002;79(2):173-80.

46. Lopez L, Arheart KL, Colan SD, Stein NS, Lopez-Mitnik G, Lin AE, et al. Turner syndrome is an independent risk factor for aortic dilation in the young. Pediatrics. 2008;121(6):e16227.

47. Aicher D, Urbich C, Zeiher A, Dimmeler S, Schäfers HJ. Endothelial nitric oxide synthase in bicuspid aortic valve disease. Ann Thorac Surg. 2007;83(4):1290-4.

48. Fowler NO, Holmes JC, Spitz H. Influence of acute hypertension on aortic valve competence. J Appl Physiol. 1975;39(6):879-84

49. Kim M, Roman MJ, Cavallini MC, Schwartz JE, Pickering TG, Devereux RB. Effect of hypertension on aortic root size and prevalence of aortic regurgitation. Hypertension. 1996;28(1):47-52.

50. Roman MJ, Devereux RB, Niles NW, Hochreiter C, Kligfield $\mathrm{P}$, Sato N, et al. Aortic root dilatation as a cause of isolated, severe aortic regurgitation. Prevalence, clinical and echocardiographic patterns, and relation to left ventricular hypertrophy and function. Ann Intern Med. 1987;106(6):800-7.

51. Linhartová K, Filipovský J, Cerbák R, Sterbáková G, Hanisová I, Beránek V. Severe aortic stenosis and its association with hypertension: analysis of clinical and echocardiographic parameters. Blood Press. 2007;16(2):122-8.

52. Kadem L, Dumesnil JG, Rieu R, Durand LG, Garcia D, Pibarot P. Impact of systemic hypertension on the assessment of aortic stenosis. Heart. 2005;91(3):354-61.

53. Pate GE. Association between aortic stenosis and hypertension. J Heart Valve Dis. 2002;11(5):612-4.

54. Kontos J, Papademetriou V, Wachtell K, Palmieri V, Liu JE, Gerdts E, et al. Impact of valvular regurgitation on left ventricular geometry and function in hypertensive patients with left ventricular hypertrophy: the LIFE study. J Hum Hypertens. 2004;18(6):431-6.

55. Gueron M, Hirsch M, Rosenman E, Borman J. Secondary mitral regurgitation and systemic hypertension. Chest. 1973;63(4):547-51.
56. Izzo JL Jr, Gradman AH. Mechanisms and management of hypertensive heart disease: from left ventricular hypertrophy to heart failure. Med Clin North Am. 2004;88(5):1257-71.

57. Bayés-Genís A, Guindo J, Viñolas X, Tomás L, Elosua R, Duran I, et al. Cardiac arrhythmias and left ventricular hypertrophy in systemic hypertension and their influences on prognosis. Am J Cardiol. 1995;76(13):54D-59D.

58. Messerli FH, Michalewicz L. Hypertensive heart disease, ventricular dysrhythmias, and sudden death. Adv Exp Med Biol. 1997;432:263-72.

59. Palmiero P, Maiello M. Arrhythmic risk in essential hypertension: late potentials. Minerva Cardioangiol. 2004;52(1):1-8.

60. Liang Q, Molkentin JD. Redefining the roles of p38 and JNK signaling in cardiac hypertrophy: dichotomy between cultured myocytes and animal models. J Mol Cell Cardiol. 2003;35(12):1385-94.

61. Natali A, Vichi S, Landi P, Toschi E, Severi S, L'abbate A, et al. Coronary artery disease and arterial hypertension: clinical, angiographic and follow-up data. J Intern Med. 2000;247(2):219-30.

62. De Lima JJ, Lopes HF, Grupi CJ, Abensur H, Giorgi MC, Krieger EM, et al. Blood pressure influences the occurrence of complex ventricular arrhythmia in hemodialysis patients. Hypertension. 1995;26(6 Pt 2):1200-3.

63. Aytemir K, Ozer N, Atalar E, Sade E, Aksöyek S, Ovünç K, et al. $\mathrm{P}$ wave dispersion on 12-lead electrocardiogram in patients with paroxysmal atrial fibrillation. Pacing Clin Electrophysiol. 2000;23(7):1109-12.

64. Maison-Blanche P, Coumel P. Changes in repolarization dynamicity and the assessment of the arrhythmic risk. Pacing Clin Electrophysiol. 1997;20(10 Pt 2):614-24.

65. Mayet J, Shahi M, McGrath K, Poulter NR, Sever PS, Foale RA, et al. Left ventricular hypertrophy and QT dispersion in hypertension. Hypertension. 1996;28(5):791-6.

66. Moser M. Hypertension treatment and the prevention of coronary heart disease in the elderly. Am Fam Physician. 1999;59(5):1248-56.

67. Levy AS, Chung JC, Kroetsch JT, Rush JW. Nitric oxide and coronary vascular endothelium adaptations in hypertension. Vasc Health Risk Manag. 2009;5:1075-87.

68. White HD, Van de Werf FJ. Thrombolysis for acute myocardial infarction. Circulation. 1998;97(16):1632-46.

69. Silber S, Albertsson P, Avilés FF, Camici PG, Colombo A, Hamm C, et al. Guidelines for percutaneous coronary interventions. The Task Force for Percutaneous Coronary 
Interventions of the European Society of Cardiology. Eur Heart J. 2005;26(8):804-47.

70. Yamaguchi H, Yokoi H, Daida H. Reasonable indication for PTCA or CABG in Japanese patients with coronary artery disease-on the basis of 11 years follow-up. Nippon Geka Gakkai Zassh. 1996;97(3):191-6.

71. Riess FC, Krankenberg H, Tübler T, Danne M. Aneurysm hybrid treatment by simultaneous replacement of ascending aorta and aortic arch and endoluminal stenting of the descending aorta. Heart Surg Forum. 2006;9(1):E530-2.

72. Obitsu Y, Shigematsu H, Uchiyama H, Iwahashi T, Nakamoto T, Watanabe Y, et al. Hybrid procedure of aortic replacement with transluminally placed endovascular grafting for multiple aortic aneurysms. Jpn J Vasc Surg. 2006;15(2):55-8.

73. Kavoussi SK, Christman GM, Smith YR. Healthcare for adolescents with Turner syndrome. J Pediatr Adolesc Gynecol. 2006;19(4):257-65.

74. Sagbas E, Akpinar B, Sanisoglu I, Caynak B, Tamtekin B, Oral $\mathrm{K}$, et al. Video-assisted bilateral epicardial pulmonary vein isolation for the treatment of lone atrial fibrillation. Ann Thorac Surg. 2007;83(5):1724-30.

75. Khargi K, Keyhan-Falsafi A, Hutten BA, Ramanna H, Lemke B, Deneke T. Surgical treatment of atrial fibrillation: a systematic review. Herzschrittmacherther Elektrophysiol. 2007;18(2):68-76.

76. McKellar SH, Zehr KJ. Aortic valve repair for aortic insufficiency. http://www.ctsnet.org/sections/clinicalresources/adultcardiac/ expert_tech-19.html. Accessed on January 9, 2011.

77. Skoularigis J, Sinovich V, Joubert G, Sareli P. Evaluation of the long-term results of mitral valve repair in 254 young patients with rheumatic mitral regurgitation. Circulation. 1994;90(5 Pt 2):II167-74. 